\title{
Foetal outcome in pregnancy complicated with viral hepatitis
}

\author{
Harshada S. Thakur*, Niranjan Maydeo, Madhuri Kamble
}

Department of Obstetrics and Gynecology, Seth Gordhandas Sunderdas Medical College, KEM Hospital, Parel, Mumbai, Maharashtra, India

Received: 14 April 2017

Accepted: 20 April 2017

\section{*Correspondence:}

Dr. Harshada S. Thakur,

E-mail: harshadatha210@gmail.com

Copyright: () the author(s), publisher and licensee Medip Academy. This is an open-access article distributed under the terms of the Creative Commons Attribution Non-Commercial License, which permits unrestricted non-commercial use, distribution, and reproduction in any medium, provided the original work is properly cited.

\section{ABSTRACT}

Background: The purpose of this study is to study foetal outcome in pregnancy complicated with viral hepatitis, rate of NICU admission and foetal death.

Methods: This is a cross sectional observational study undertaken in the Department of Obstetrics and Gynaecology at the tertiary care centre for the study period from October 2015 to October 2016 approved by ethical committee.

Results: There were 6555 deliveries in study period of October 2015-2016 in which 54 patients were diagnosed with viral hepatitis in pregnancy. Out of 54 patients of viral hepatitis, 30 cases (55.55\%) of Hepatitis E virus, 22 cases $(40.74 \%)$ of Hepatitis B virus, 2 cases $(3.7 \%)$ of Hepatitis C virus. No case was found for Hepatitis A virus infection. Higher incidence of NICU admission (56.66\%), preterm delivery (36.66\%) and intra uterine death $(23.33 \%)$ was observed with Hepatitis E infection.

Conclusions: Foetal outcome was poor in Hepatitis E virus followed by Hepatitis B virus. Acute viral hepatitis is more common cause of hepatitis in pregnancy. Hepatitis $\mathrm{E}$ virus was the most common cause of acute infection with adverse fetal outcome. Fetal loss including intra uterine death and preterm neonate was statistically significant with Hepatitis E viral infection. Health education, early diagnosis and multidisciplinary approach is the key to reduce foetal morbidity and mortality. As HBV infection in hepatitis in pregnancy is second most common cause of viral hepatitis, complete immunization against $\mathrm{HBV}$ in reproductive age group before first pregnancy is recommended.

Keywords: Hepatitis, Hepatitis E virus, Intrauterine death

\section{INTRODUCTION}

Hepatitis in pregnancy is associated with high maternal and perinatal mortality rates. It is one of the major causes of maternal death, responsible for $5-30 \%$ of all maternal deaths. ${ }^{1}$

Viral hepatitis is the most common cause of jaundice in pregnancy among all causes affecting fetuses as abortion, stillbirths, NICU admission and neonatal death.

Incidence of viral hepatitis varies around the world. In developing countries, it can range from $3-20 \%$ in contrast to developed countries where it is hardly $0.1 \%$. $^{2}$

\section{Acute viral hepatitis}

Acute viral hepatitis is a systemic infection affecting the liver predominantly more often subclinical. It is usually self-limited liver disease. It is characterized by serum aspartate aminotransferase elevation of at least five-fold or clinical jaundice or both. ${ }^{3}$ Almost all cases of acute viral hepatitis are caused by one of five viral agents: hepatitis A virus (HAV), hepatitis B virus (HBV), hepatitis $\mathrm{C}$ virus (HCV), the $\mathrm{HBV}$-associated delta agent or hepatitis D virus (HDV), and hepatitis E virus (HEV). ${ }^{4}$ Acute liver failure (ALF) is considered when the patient after having a typical acute hepatitis, develops hepatic encephalopathy within four weeks. It is characterized by 
mental changes progressing from confusion to stupor and coma as a result of severe impairment of hepatic function, without any history of pre-existing liver disease.

\section{Chronic hepatitis}

Chronic infection follows after hepatitis B and hepatitis C infection with subsequent development of chronic hepatitis. It is usually diagnosed serologically.

\section{Hepatitis and its relationship with pregnancy}

Pregnancy appears to be a potential risk factor for viral replication and leads extreme low immune status of pregnant women. Malnutrition superimposed on the normal demands of pregnancy and inversion of $\mathrm{T}$ and $\mathrm{B}$ lymphocytes in early pregnancy have been postulated to be the contributing factors for high level of incidence and complications. Acute hepatitis A is self-limiting disease. Its prognosis in pregnancy is same as that in nonpregnant patient.

Hepatitis B infection in pregnant woman has to be differentiated from acute infection and chronic carrier state. In outbreaks of waterborne hepatitis $\mathrm{E}$ in India and Asia, the case-fatality rate is $1-2 \%$ and up to $10-20 \%$ in pregnant women. Mortality rates among pregnant women, especially those infected in the $3^{\text {rd }}$ trimester, have ranged between $15 \%$ and $25 \%$, much higher that men and non-pregnant women. It has got high incidence of abortion, foetal death and still birth. ${ }^{5}$ Only $25 \%$ of patients infected with Hepatitis $\mathrm{C}$ infection develops acute hepatitis and majority remains asymptomatic with tendency to chronic hepatitis. Chronic infection with HCV does not have any adverse effect on pregnancy outcome. Available review of literature showed that there is wide variation in clinical course and fetal outcome of viral hepatitis in pregnancy. ${ }^{6}$ This observational cross sectional study was undertaken to determine foetal outcome in pregnant women complicated with viral hepatitis.

\section{METHODS}

Type of study: Cross sectional observational study. Study area: Department of Obstetrics and Gynecology and Department of Medicine, Seth GS Medical College, KEM Hospital, Parel. Mumbai, India, 400012. Population: All records of women with viral hepatitis delivered in KEM hospital, Mumbai.

\section{Inclusion criteria}

All records of women with viral hepatitis delivered in K.E.M. hospital.

\section{Exclusion criteria}

- All records of women with hepatitis with non-viral origin.
- All records of women with viral hepatitis delivered outside K.E.M. hospital.

- All records of pregnant women with viral hepatitis not delivered in study period October 2015 to October 2016.

- All records of women with viral hepatitis with other medical illness like hypertension, diabetes, preeclampsia, heart disease etc.

Study period: October 2015 to October 2016. Sample Size: 54 cases of viral hepatitis in pregnancy were studied for the study duration from October 2015 to October 2016. Statistical value calculated using SPSS software. Study was initiated only after ethics committee's permission. Patient fulfilling the inclusion criteria were enrolled into study. Waiver of consent was sought from IEC. Data regarding maternal sociodemographic characteristics and clinical profile were obtained and its effect on foetal outcome were studied and inferences were drawn regarding the same.

\section{Outcome measured}

- Foetal outcome

- Number of abortions, intrauterine foetal death, still births

- Number of preterm deliveries

- Need for NICU admission

- Neonatal mortality

The data collected and results arrived upon will help contribute scientific literature regarding viral hepatitis in pregnancy, and help in betterment of foetal outcome in same.

\section{RESULTS}

There were 6555 deliveries in study duration from October 2015-October 2016. There were 54 diagnosed patients of viral hepatitis in pregnancy. The distribution of type of virus causing viral hepatitis in pregnancy.

Out of these 54 patients, 30 cases $(55.55 \%)$ of were Hepatitis E virus, 22 cases $(40.74 \%)$ were of Hepatitis B virus and 2 cases $(3.7 \%)$ were of Hepatitis $\mathrm{C}$ virus. No case was seen with Hepatitis A virus infection in pregnancy. Adverse foetal outcome was observed with Hepatitis E infection (Table 1).

Table 1: Distribution of type of hepatitis virus in pregnant women with viral hepatitis.

\begin{tabular}{|lll|}
\hline Type of hepatitis virus & $\begin{array}{l}\text { Total no. of } \\
\text { patients (54) }\end{array}$ & $\%$ \\
\hline HEV & 30 & 55.55 \\
\hline HBV & 22 & 40.74 \\
\hline HCV & 2 & 3.70 \\
\hline HAV & 0 & 0 \\
\hline
\end{tabular}




\section{Foetal outcome in our study is as follows}

In $\mathrm{HEV}$ infection, 17 out of 30 deliveries i.e.56.66\% required NICU admission, 11 patients (36.66\%) had preterm vaginal delivery, $7(23.33 \%)$ patients had intrauterine foetal death while $6(20 \%)$ were IUGR and 4 i.e. $13.33 \%$ were still birth. In $\mathrm{HBV}$ infection in pregnancy, 5 (22.72\%) out of 22 patients, 5 (22.72\%) had preterm vaginal delivery, $6(27.27 \%)$ babies needed
NICU admission while 3 patients i.e. $13.6 \%$ had abortion. There were 3 neonatal death with HEV infection while no neonatal death was observed for HBV infection in pregnancy. There was no case of HAV infection in pregnancy in study duration. 2 cases $(3.7 \%)$ were observed with serologically proven $\mathrm{HCV}$ infection in pregnancy, both these patients had full term normal vaginal delivery with live born and birth weight $>2.5 \mathrm{~kg}$ (Table 2).

Table 2: Foetal outcome in pregnant women with viral hepatitis.

\begin{tabular}{|lllllll|}
\hline Foetal outcome & HEV $(\mathbf{n}=\mathbf{3 0})$ & HEV $\%$ & HBV $(\mathbf{n}=\mathbf{2 2})$ & HBV $\%$ & HCV $(\mathbf{n = 2})$ & HCV \% \\
\hline Live birth & 19 & 63.33 & 18 & 81.81 & 2 & 100 \\
\hline IUGR & 6 & 20 & 1 & 4.5 & - & - \\
\hline Still birth & 4 & 13.33 & 1 & 4.5 & - & - \\
\hline IUFD & 7 & 23.33 & 0 & 0 & - & - \\
\hline Abortion & 0 & 0 & 3 & 13.6 & - & - \\
\hline NICU admission & 17 & 56.66 & 6 & 27.27 & - & - \\
\hline Neonatal death & 3 & 10 & 0 & 0 & - & - \\
\hline Preterm delivery & 11 & 36.66 & 5 & 22.72 & - & - \\
\hline
\end{tabular}

\section{DISCUSSION}

Viral hepatitis in pregnancy and its fetal outcome has a lot of discussions and debate all the world. Various studies have shown various diversity in reporting no difference in fetal outcome to as severe as mortality. Viral hepatitis of acute variety is a major public health concern. Incidence of hepatitis in pregnancy varies around the world. It is around $0.1 \%$ in developed countries and $3-20 \%$ or higher in developing countries. ${ }^{2}$

Viral hepatitis in pregnancy attributed to viruses A, B, C, $\mathrm{D}$ and $\mathrm{E}$. Among these hepatitis, $\mathrm{E}$ is the most common causing $50-70 \%$ of all patients. ${ }^{2}$ Saima Wani et al studied 80 cases of viral hepatitis out of which $25 \%$ were serologically positive $\mathrm{HbsAg}$ and $45 \%$ positive for hepatitis E infection. They had no case of HAV and HCV infection in pregnancy. ${ }^{8}$ Shweta Sahai et al studied 68 pregnant women with viral hepatitis and found out $7.4 \%$ cases of $\mathrm{HBV}, 77.9 \%$ cases of $\mathrm{HEV}, 1$ case of $\mathrm{HCV}$ and no case of HAV. ${ }^{6}$ In our study, we had 6555 deliveries in one year of study duration out of which 54 were diagnosed cases of viral hepatitis. Among these 54 patients, 30 cases $(55.55 \%)$ of were Hepatitis E virus, 22 cases $(40.74 \%)$ were of Hepatitis B virus and 2 cases (3.7\%) were of Hepatitis C virus. No case was seen with Hepatitis A virus infection in pregnancy. Hepatitis $\mathrm{E}$ virus is single stranded RNA non-enveloped virus and most common cause of acute hepatitis in pregnancy. It is emerging infectious disease of global importance. ${ }^{9}$ It is transmitted through faecal-oral route by drinking contaminated water and major public health concern. ${ }^{10}$ Same study had noticed that $65 \%$ pregnant women with HEV patients had preterm deliveries. They also noticed $8.3 \%$ of patients had miscarriage. Jethwa DK et al had observed $72 \%$ of pregnant women with HEV had preterm deliveries. In the same study, $33.3 \%$ had intra uterine death and $69 \%$ required NICU admission. They had $66.6 \%$ live born while $54 \%$ were low birth weight. Reasons for these poor fetal outcome with HEV attributed to preterm deliveries, low birth weight, fever, vertical transmission and general poor sanitation. ${ }^{11}$ In a study done by Saima et al studied 36 cases of HEV in pregnancy and found $33 \%$ patients had preterm deliveries while $11 \%$ had intrauterine fetal death. ${ }^{8}$ In our study, 17 out of 30 deliveries i.e. $56.66 \%$ required NICU admission, 11 patients $(36.66 \%)$ had preterm vaginal delivery, $7(23.33 \%)$ patients had intrauterine foetal death while $6(20 \%)$ were IUGR and 4 i.e. $13.33 \%$ were still birth in HEV infection in pregnancy. We observed that 19 i.e. $63.33 \%$ were live born with HEV infection.

Hepatitis B virus is transmitted vertically in $60 \%$ of unborn children. ${ }^{6}$ Saima Wani et al had observed $20 \%$ had abortion, $75 \%$ patients had preterm deliveries, $31 \%$ intrauterine fetal death and $1 \%$ still birth in $\mathrm{HbsAg}$ positive patients in her study conducted in 2013 in Kashmir. ${ }^{8}$ In HBV infection in pregnancy in our study, $5(22.72 \%)$ out of 22 patients $5(22.72 \%)$ had preterm vaginal delivery, $6(27.27 \%)$ babies needed NICU admission while 3 patients i.e. $13.6 \%$ had abortion. There were 3 neonatal death with HEV infection while no neonatal death was observed for $\mathrm{HBV}$ infection in pregnancy. Hepatitis A virus is transmitted by faecal-oral route and does not influence fetal outcome. ${ }^{5}$ We had no pregnant woman infected with HAV. Our observation is similar to study done by Suruchi Shukla who had no patient infected with HAV. In a study done by Suruchi Shukla had found $4 \%$ incidence of $\mathrm{HCV}$ as a cause of hepatitis in pregnancy. ${ }^{2}$ In our study we had 2 cases of serologically proven HCV hepatitis in pregnancy. These patients had no signs or symptoms of acute viral hepatitis 
and underwent full-term normal vaginal delivery with live baby weight appropriate for the gestational age. Study done by Khuroo et al also reported low prevalence of HCV. ${ }^{11}$ Suruchi Shukla et al had studied that preterm delivery is the main complication in pregnant women with viral hepatitis. In the same study $17 \%$ of patients had preterm delivery which is consistent with our study $6 \%$ patients had intra uterine fetal death with all these patients infected with $\mathrm{HEV}$ and $5.3 \%$ and $30.8 \%$ had neonatal death and low birth weight respectively. They observed as $42 \%$ of pregnant women infected with viral hepatitis had poor fetal outcome. ${ }^{2}$ In a study done by Mishra $\mathrm{S}$ et al in 105 patients of hepatitis $\mathrm{E}$ in pregnancy, $56.19 \%$ delivered full term while $30.48 \%$ had preterm delivery. ${ }^{8}$ Shweta Sahai et al in their study observed $42.61 \%$ had poor fetal outcome in HEV infection in pregnancy which constitutes intra uterine fetal and neonatal death. They observed 3 out of 10 neonates had vertical transmission, out of which 2 had Hepatitis E and 1 had Hepatitis B. ${ }^{6}$ In a study done by Anwar Bassam et al had noticed higher incidence of fetal complications with $\mathrm{HEV}$ in pregnancy which was $12.5 \%$ intra uterine death, $25 \%$ preterm labour and low birth weight each as compared to $5 \%$ intra uterine death in HAV and $12.5 \%$ for $\mathrm{HBV}$ in pregnancy with no neonatal death. ${ }^{12}$ Our study shows incidence of preterm vaginal delivery was $36.66 \%$ in $\mathrm{HEV}$ infection while $22.72 \%$ with HBV infection. There were $23.33 \%$ intra uterine foetal death in HEV infection and $10 \%$ had neonatal death. IUGR incidence was $20 \%$ and $4.5 \%$ for $\mathrm{HEV}$ and $\mathrm{HBV}$ respectively.

\section{CONCLUSION}

In present series, study of pregnant women complicated with viral hepatitis was done during the period of October 2015 to October 2016. Acute viral hepatitis is more common cause of hepatitis in pregnancy. Hepatitis E virus was the most common cause of acute infection with adverse fetal outcome. Fetal loss including intra uterine death and preterm neonate was statistically significant with Hepatitis E viral infection. In a developing country like India, health education to pregnant women about viral hepatitis and visit to medical personnel with early transfer to tertiary care centre for early diagnosis and prompt multidisciplinary approach is utmost important to prevent perinatal morbidity and mortality. As hepatitis A and $\mathrm{E}$ viruses transmitted by fecal-oral route, Government should make sure to supply safe sanitation and potable drinking water to public. As HBV infection in hepatitis in pregnancy is second most common cause of viral hepatitis, complete immunization against $\mathrm{HBV}$ in reproductive age group before first pregnancy is recommended.
Funding: No funding sources

Conflict of interest: None declared

Ethical approval: The study was approved by the Institutional Ethics Committee, Seth G.S. Medical College, KEM Hospital, Parel, Mumbai, India.

\section{REFERENCES}

1. Cunningham G, Leveno KJ, Bloom SL. Hepatic, gallbladder, and pancreatic disorders. Williams Obstetrics. 23 $3^{\text {rd }}$ ed, New York, Mac Graw Hill; 2010: 1063.

2. Shukla S, Mehta G, Jais M, Singh A. A Prospective Study on Acute Viral Hepatitis in Pregnancy; Seroprevalence, and Fetomaternal Outcome of 100 cases. J Biosci Tech. 2011;2 (3):279-86.

3. Smedile A, Carcil, Verme G. Influence of delta infection on severity of hepatitis B. Lancet. 1982;2:945-7.

4. Acute Viral Hepatitis. Harrison's Principles of Internal Medicine. 17th Edition. New York, McGraw Hill: Chapter 298.

5. Lal S, Makharia GK. Liver disorders, Ian Donald. $7^{\text {th }}$ edition; 226-31.

6. Sahai S, Mishra V, Ganga D, Jatav OP. Viral Hepatitis in Pregnancy -A study of its Effect on Maternal and Foetal Outcome. J Assoc Physic India. 2015;23:28-33.

7. Wani S, Kadri SM, Bhat S. Prevalence of acute viral hepatitis in women presenting with jaundice with fetomaternal outcome. GJMEDPH. 2013;2(6):1-5.

8. Mishra S, Jha RK, Thakur R, Tiwari S. Study of maternal and prenatal outcome in pregnant women with acute hepatitis $\mathrm{E}$ viral infection. Int $\mathrm{J}$ Reprod Contracept Obstet Gynecol. 2016;5(7):2300-3.

9. Nadar S, Shah MA, Jamil S, Habib H. Maternal and Foetal Outcome in Pregnant Ladies having Acute Hepatitis E. Gomal J Med Sci. 2015;13(1):37-40.

10. Jethwa DK, Chauhan DV, Badrakiya GL, Badrakiya SG. Hepatitis E virus in pregnancy with fetomaternal outcome-A prospective study. IOSR J Dent Med Sci. 2015;14(8):25-8.

11. Khuroo MS, Kamili S. Aetiology, clinical course and outcome of sporadic acute viral hepatitis in pregnancy. J Viral Hepat. 2003;10:61-9.

12. Anwar AL Bassam, Laith A, Yasin A. Outcome of viral hepatitis in pregnancy. Iraqui $\mathrm{J}$ Gastroenterol. 2007;2(1):48-53.

Cite this article as: Thakur HS, Maydeo N, Kamble M. Foetal outcome in pregnancy complicated with viral hepatitis. Int J Reprod Contracept Obstet Gynecol 2017;6:2073-6. 